\title{
Impact of Treasury Single Account on the Liquidity
}

\section{Clementina Kanu}

Department of Accountancy, Federal University Ndufu Alike Ikwo, PBM 1010, Abakaliki, Ebonyi, NIGERIA

*Corresponding Contact:

Email: $\underline{\text { srmenfu2009@gmail.com }}$

\begin{abstract}
The introduction of Treasury Single Account is as a result of numerous corrupt practices that exist in the Country's public accounting system, lack of transparency and accountability. The paper assesses the positive effect of implementation of TSA on the Economy, the public accounting system and the undesired consequences on the liquidity base and performance of banking sector in Nigeria. We administered questionnaires to the Management staff of the ten banks selected for the study. We employed Chi-square as a statistical tool for analysis of the data. The results obtained confirmed that the implementation of Treasury Single Account in the public accounting system impacted negatively on the liquidity base and the performance of banking sector in Nigeria. We, therefore 7 recommend that CBN and the Government should come up with an arrangement to address the issue of TSA considering the impact of the activities as the important 9 factor for efficient management, control of government's cash resources as well as sustainability of banks. CBN should go beyond the guidelines and put in place measures to correct any lapses or negative impact of the policy both in the banking sector and the economy at large. The implication of the study is that banks should avoid armchair activities and go to other source of funds in the economy. Many people that are denied access to credit facilities, investments and savings opportunity should be encouraged as this will improve the economy and result in sustainable banking sector in the country.
\end{abstract}

Keywords: Treasury Single Account, Banking sector, Banks liquidity base, and performance, Public accounting system, corruption and economy

How to Cite: Kanu C. 2016. Impact of Treasury Single Account on the Liquidity ABC Journal of Advanced Research, 5, 43-52.

This article is is licensed under a Creative Commons Attribution-NonCommercial 4.0 International License.

Attribution-NonCommercial (CC BY-NC) license lets others remix, tweak, and build upon work non-commercially, and although the new works must also acknowledge \& be non-commercial.

\section{INTRODUCTION}

Since 1952, banks in Nigeria have experienced several reforms and policies. Many banks did not survive these experiences. The economic status of any nation depends on how stable their banking industry is. In other words, any issue that affects banks also has an impact on the economy of the nation. Until the introduction of TSA in Nigeria, MDA's which generate 
revenue, have the multiplicity of accounts in commercial banks, use part of the revenue generated to fund their operations and then remit the surplus to the federation account. As a result, agencies pay into government account what they deem fit. Under this situation, some ministries became richer than a government. The result of this situation includes leakages of funds, embezzlement of public funds, the inability of a government to know the exact amount in its account. Budgets were therefore prepared using false projection leading to poor implementation. However, the greatest beneficiaries of this situation were the banks that relied on the deposits from the ministries (public money) and government borrowings from banks with high- interest rate. Above all, banks no longer care to mobilize money from other sectors of the economy. The balances of account of the government with the banks lay idle in the banks. All these stunted the growth of the economy. The above background resulted in the recent demand by the Presidency that all agencies and ministries should close their accounts with Commercial banks and transfer the balances into federation account with Central Bank of Nigeria. This directive conveyed in a CBN circular no. BPS/CSO/CON/DIR/01/079.Dated: February 25, 2015, and addressed to all Deposit Money Banks (DMB). The circular was entitled "Commencement of federal government's independent revenue e collection scheme under the single treasury account (TSA) initiative".

IMF (2010), defined TSA as a" unified structure of government bank accounts that gives a consolidated view of government cash resources. Based on this principle and the unity of treasury, a TSA is a bank account or a set of linked accounts through which the government transacts all its receipts and payments". Adeolum, (2015) added that "the maintenance of Treasury Single Account will help to ensure proper cash management by eliminating idle funds usually left with different commercial banks and in a way enhance reconciliation of revenue collection and payment".

Treasury Single Account will cause cash crunch and liquidity challenges to the banking sector, who before the introduction of the TSA feed fat on the "float" created by the duplicated and unaccounted MDA's accounts in all the Commercial Banks in Nigeria. The question is: what is the impact of this TSA on the banks' liquidity and performance in Nigeria?

The objective of this paper is to find out the influence of TSA on the liquidity base and performance of the banking sector in Nigeria. We structured the paper into four parts. Following this introduction is Part 2 , which looks at the related literature, part 3 discusses the methodology, part 4 presents the analysis and implication of findings while part 5 is the conclusion and recommendation.

$\mathrm{H}_{0}$ : There is no significant relationship between TSA, banks' liquidity and banks' performance

\section{CONCEPT OF TSA}

Treasury Single Account (TSA) is one of the financial policies implemented by the federal government of Nigeria to consolidate all the revenue from all the ministries, departments, and agencies (MDAs) in the country by way of deposit into Commercial banks traceable into a single account at the Central Bank of the country. The policy was introduced to reduce the proliferation of bank accounts operated by MDAs and also to promote transparency and accountability among all organs of the government Tayo A. (2015), said that TSA is "the Federal Government independent Revenue e-collection initiative that will automate Revenue Collections of Ministries, Departments, and Agencies (MDAs) directly into the Federal Government Consolidated Revenue Fund (CFR) account at the CBN through the Remita e collection platform and other electronic payment channels". 
The adoption of TSA will involve retail banking which commercial banks can perform. It includes: collection of taxes/levies and disbursements of funds as well as payment of salaries to civil servants.

As a public accounting system, the primary aim of TSA is to ensure accountability of government revenue, enhance transparency and avoid misapplication of public funds. It is to ensure that transparency on unspent budgetary allocations is carried forward automatically to another year.

Section 80 (1) of the 1999 Constitution as amended states that "all revenue or other money raised or received by the Federation (not being revenue or other money payable under this Constitution or any Act of the National Assembly into any other public fund

of the Federation established for a specific purpose) shall be paid into and form one Consolidated Revenue Fund of the Federation". Successive governments have continued to operate multiple accounts for the collection and spending of revenue, thereby disregarding the provision of the constitution which require the remittance of all the revenue into a single account.

It was not until 2012 that government ran a pilot scheme for a single account using 217 ministries, department and agencies as a test case. The exercise saved Nigeria about N500 billion in frivolous spending. The success of the pilot motivated the government to implement fully TSA, leading to the directives to banks to provide the technology platform that will help to accommodate the TSA. The Central Bank opened a Consolidated Revenue Account to receive all government revenue and effect payments through this account. All Ministries, Departments, and Agencies are expected to remit money collected in to this account through the individual commercial banks who act as collection agents. Although, commercial banks will continue to maintain revenue collection accounts for Ministries, Departments, and Agencies but all monies collected by these banks will have to be remitted to the Consolidated Revenue Accounts with the CBN at the end of each banking day. In other words, Ministries, Departments, and Agencies accounts with money deposit banks must have nil balance at the end of every working day by a complete remittance to the Treasury Single Account, of all revenues collected. The implication is that banks will no longer have access to the float provided by the accounts they maintained for the Ministries, Departments, and Agencies.

According to IMF(2010), full-fledged TSA shares three essential features:

- First, the government banking arrangement should be unified, to enable the ministry of Finance (MoF) (or treasury) to have an oversight responsibility for, over government cash flows in and out of these bank accounts.

- Second, no other government agency operates bank accounts outside the treasury single account arrangement.

- Third, the consolidation of resources should be comprehensive, and encompass all funds both budgetary and extra-budgetary.

Therefore, the TSA is a payment system in which all revenues due to the government are paid 88 into a unified account domiciled with the CBN. Its objective is to ensure fiscal discipline and transparent management of the nation's finances. (CBN, 2015). 


\section{TSA AND BANKING SECTOR}

The banking sector is the engine of any nation's economy. In Nigeria, commercial banks have been the custodians of government funds. Therefore, with the maintenance of a single account, banks will be deprived of the free flow of funds from ministries.

Indeed, it is estimated that commercial banks hold about N2.2 trillion public sector funds at the beginning of the first quarter of 2015. When such amount of money leaves the system is obvious. When one considers the fact that each time the monthly federal allocation is released, the banking system is usually awash with liquidity, and as soon as this public sector fund dries up, the result is liquidity problem with an increase in interbank rates. The banks must be affected, when such high revenue generating parastatals like the NNPC moves out of commercial banks. As a matter of fact, commercial banks stand to lose immensely from the implementation of Treasury Single Account. This cause insufficiency of available cash in the banking system, resulting in a surge in money market rates during the period as banks source for funds to cover their poor liquidity positions. Indeed, the Nigerian banking industry, on an aggregate basis, would be affected regarding deposits and funding cost structure. As a matter of fact, TSA generated much fear in the banking industry even before its implementation. The fear is that with the high Monetary Policy Rate at 13\%, Cash Reserve Ratio (CRR) at 20\% and 75\% available for private and public sector deposits respectively, its implementation would not be favorable to banks.

Irrespective of how tough his policy will be on banks, it will perhaps compel the banks to focus on the funds of the real sector of the economy, rather than spending much on Federal Government projects, Oil \& Gas Transactions , Forex dealings , etc. Any commercial bank that fails to operate based on the core banking functions for which they were licensed must definitely close shop. This will cause heavy downsizing of staff, thereby increasing the unemployment rate in the country. Managements of banks should understand the aim of establishing banks. The Government is not only customer banks have. The issue of banks chasing government money at the expense of other clients especially in the sector of the economy is a questionable commentary on the performance of the banks.

A good number of people in Nigeria is unserved by the bank, many lack access to financial services, and some have no opportunity to save or invest their resources. To affirm this, Kanu \& Oyims (2015) observe that "in most developing countries, the formal financial system reaches only to top 25 per cent of the economically active population" According to the authors, 75 percent of the people were left without access to financial services apart from those provided by money lenders and families. The issue of the non accessibility to financial service cause poor economic sustainability and rural development in Nigeria.

The adoption of the TSA is in the greater interest of the states, as it will pave the way for the timely payment and capturing of all government revenue in a single government treasury account, without the intermediation of multiple banking arrangements as had been the case. Moreover, embracing the scheme can help reduce the mismanagement of public funds by revenue-generating agencies, as well as check excess liquidity, inflation, high interest rates and round-tripping of the government deposits. The use of multiple bank accounts left room for the misappropriation of huge sums of money belonging to all levels of government in the country. It encouraged unbridled corruption in the management of public finances, with the result that all tiers of governments became heavily cash-strapped. 


\section{Treasury Single Account AND ECONOMY}

Government sees Treasury Single Account as a useful tool to establish centralized control over its revenue through effective cash management. It enhances accountability and enables government to know how much is accruing to its accounts on a daily basis. In Nigeria, it is expected that the implementation of TSA will help tame the tide of corruption of financial leakages and embezzlement. The implementation of Single Treasury Account (TSA) is expected to block revenue leakages within the government parastatals as the Ministry of Finance will be able to monitor the inflows and outflows, hence, augment the reduction in oil revenue due to falling oil prices. CBN, (2015) reasoned in the same direction and said that the implementation of TSA will enable the Ministry of Finance to monitor fund flow as no agency of government is allowed to maintain any operational bank account outside the oversight of the ministry of finance.

The implementation of the TSA will have a positive effect on the national economic planning, swift \& full budgetary implementation; reduce leakages and other irregularities in the MDAs, aid appropriate planning, data collection, analysis and timely aggregation of Federal Government Revenue. Realization of the government revenue on time causes its effective allocation.

The primary benefit of a Treasury Single Account is to provide for proper monitoring of government receipts and expenditure. In the Nigerian case, it will help to block most, if not all, the leakages that have been the bane of the economy. We have a situation where some Ministries, Departments, and Agencies manage their finances like independent empires and remit limited revenue to government treasury. Under a properly run Treasury Single Account, it cannot be possible, an agencies of government are meant to spend in line with duly approved budget provisions. Tayo A. (2015), said that "Government should make banking arrangements for efficient management and control of government's cash resources". It should be designed to minimize the cost of government borrowing and maximize the opportunity cost of fund. TSA ensures that all money received is available for carrying out government's expenditure program and making payments on time. Many low-income countries have fragmented systems for handling government receipts and payments. In these countries, the ministry of finance/treasury lacks a unified view and centralized control over government's cash resources. As a result, this fund lies idle for extended periods in numerous bank accounts held by spending agencies while the government continues to borrow to execute its budget.

Hence, Udoma U. U. (2016) opines that maintenance of TSA will enhance funding government budget rather than depend on Federal allocation. In any economy where the budget is fully funded, the aim certainly will be accomplished. The consequence should be; improved economic system, political and social development.

IMF (2010), made it clear in her working paper that a government that lacks effective control over its cash resources can pay for its institutional deficiencies in multiple ways. First, idle cash balances in bank accounts often fail to earn market-related remuneration.

Second, the government, being unaware of these resources, incurs unnecessary borrowing costs on raising funds to cover a perceived cash shortage. Third, idle government cash balances in the commercial banks are not idle for the banks themselves, and can be used to extend credit. These have been the case in Nigerian economy. Nigeria still owes a huge amount in both external and internal debts. Therefore, the implementation of TSA will promote a healthy economic system. Hence, a member of the Monetary Policy Committee 
(MPC), in his contribution said: "it has indeed become very clear that total economic restructuring is an urgent imperative. Although the falling oil price is making the fiscal space more complicated, I believe that there is still room for improvement. One area that can be easily improved upon is the reduction of wastages in government finances, which is as a result of poor financial management. By far the greatest single example of this is the absence of the Treasury Single Account (TSA)".

The IMF in a 2010 paper titled Treasury Single Account: Concept, Design, and Implementation Issues, outlined the benefits of operating a Treasury Single Account. It started by explaining that the primary objective of a TSA is to ensure effective aggregate control over government cash balances. Here are the benefits:

- Allows complete and timely information on government revenue in countries with advanced payment and settlement systems and an Integrated Financial Management Information System (IFMIS) with adequate interfaces with the banking system, this information will be available in real time. As a minimum, required and updated balances should be available daily.

- Improves appropriation control. The TSA ensures that the MoF has full control over budget allocations, and strengthens the authority of the budget appropriation. The result of maintaining separate bank accounts is often system, where funds provided for budgetary appropriations are augmented by additional cash resources that become available through various creative, often extra-budgetary, measures.

- Improves operational control during budget execution. When the Treasury has full information about cash resources, it can plan and implement budget in an efficient, transparent, and reliable manner. The existence of uncertainty regarding whether the Treasury will have sufficient funds to finance program expenditures may lead to sub-optimal behavior by budget entities, such as exaggerating their estimates for cash needs or channeling costs through off-budget arrangements.

- Enables efficient fund management. A TSA facilitates regular monitoring of government cash balances. It also enables higher quality inflow and out flow outturn analysis to be undertaken (e.g., identifying causal factors of variances and distinguishing causal factors from random variations in cash balances 183)

- Elimination of bank fees and transaction costs. Reducing the number of bank accounts results in a lower administrative cost for the government for maintaining these accounts, including the cost associated with bank reconciliation, and reduced banking fees.

- Facilitates efficient payment mechanisms. A TSA ensures that there is no ambiguity regarding the volume or the location of the government funds, and makes it possible to monitor payment mechanisms precisely. It can result in substantially lower transaction costs because of economies of scale in processing settlements. In establishment of a TSA, it is combined with the elimination of the "float" in the banking and the payment systems, and the introduction of transparent fee and penalty structures for payment services. Many governments have achieved substantial reductions in their real cost of banking services by introducing a TSA.

- Improves bank reconciliation and quality of fiscal accounting system. A TSA allows for effective reconciliation between the government accounting systems and cash flow statements from the banking system. TSA also eliminates 1 the risk of errors in reconciliation of financial statements and improves the timeliness and quality of the fiscal accounts.

- Lowers liquidity reserve needs. A TSA reduces the speedy of cash flows through the treasury, thus allowing it to maintain a lower cash reserve/buffer to meet unexpected fiscal volatility. 


\section{Research Methodology}

We employed a cross- sectional survey design for this work. The population of the study is made up of 24 banks in Nigeria. We selected Ten (10) banks as sample for the study. We collected data through primary source. In order to draw conclusion, we tested the hypothesis. Government has a huge amount of deposits in these ten selected banks. Primary data were collected via structured questionnaire and administered by, on the officers of the banks which consist of The Managing Directors, Accountants, Credit Officers, Risk Managers and Marketing Managers. We decided to use them as the target of the population because of their length of services, experiences and positions in the banks. We structured the questionnaire into two sections.

Section (a) captured the personal data of respondents and section (b) obtained information from responded on the questionnaire on the influence of implementation of TSA on the liquidity base and performance of banking system in Nigeria. The work employs both descriptive and inferential statics for data analysis. Chi - square independence and homogeneity were used to test the hypothesis of the study.

The chi-square test statistics is:

$\mathrm{X}^{2}=\sum_{\mathrm{Ei}}^{\sum^{(\mathrm{oi}-\mathrm{Ei})} \text { where. }}$

$\mathrm{K}=$ Number of cells in the contingency table.

Oi $=$ Observed frequency of value.

$\mathrm{Ei}=$ Expected frequency of Value of and is calculated as follows:

(Column i total)(Row i total)

Sample Size

At 5\% significance level, where (r-1) (c -1) is the degree of freedom.

Null hypothesis for the study states thus:

$\mathrm{H}_{0}$ : Implementation of Treasury Single Account has no influence on the liquidity base and performance of the banking sector in Nigeria.

\section{Presentation and Analysis of Data}

Table one: Years of Service of respondents

\begin{tabular}{|l|l|l|}
\hline Duration of work (years) & Number of Respondent & Percentage (\%) \\
\hline $0-1$ & 0 & 0 \\
\hline $1-5$ & 6 & 22.22 \\
\hline $5-10$ & 9 & 33.33 \\
\hline 10 above & 12 & 44.45 \\
\hline Total & 27 & 100 \\
\hline
\end{tabular}

Source: Questionnaire Administered 2016

9 respondents have worked in their banks for five years and above and 12 have worked for 10years and above, totalling 21 respondents representing $77.8 \%$ of the total respondents. This implies that most of the people that answered the questions are experienced, therefore may give useful information required for the study. 
Table two: Implementation of treasury single Account

\begin{tabular}{|l|l|l|}
\hline Opinion & Compliance & Percentage \\
\hline Yes & 21 & 77.78 \\
\hline No & 6 & 22.2 \\
\hline Total & 27 & 100 \\
\hline
\end{tabular}

Source: Questionnaire Administered 2016.

Twenty -one (21) respondents, representing $77.8 \%$ of the people that answered the questions agree that TSA has been implemented, showing compliance with the provision of FRN, 1999 Constitution sec.80(1).

Table three: Influence of implementation of TSA on liquidity base of banking sector

\begin{tabular}{|l|l|l|}
\hline Opinion & Number of Respondents & Percentage (\%) \\
\hline Yes & 20 & 74.1 \\
\hline No & 7 & 25.9 \\
\hline Total & 27 & 100 \\
\hline
\end{tabular}

Source: Questionnaire Administered 2016.

In Table 3 above, twenty respondents representing $74.1 \%$ agree that implementation of TSA impacted on banking sector's liquidity base.

Table four: Influence of implementation of TSA on the performance of the banking sector

\begin{tabular}{|l|l|l|}
\hline Opinion & Number of Respondents & Percentage (\%) \\
\hline Yes & 21 & 77.8 \\
\hline No & 6 & 22.2 \\
\hline Total & 27 & 100 \\
\hline
\end{tabular}

Source: Questionnaire Administered 2016.

The above table indicates that twenty one respondents representing $77.8 \%$. agree that implementation of TSA impacted on the performance of banking sector while six respondents said the opposite.

Computation of chi-square:

\begin{tabular}{|l|l|l|l|l|}
\hline Fo & Fe & F0-fe & ${\text { (fo-fe })^{2}}$ & (fo-fe $^{2}$ fe \\
\hline 21 & 13.5 & 7.5 & 56.25 & 4.19 \\
\hline 6 & 13.5 & -7.5 & 56.25 & 4.19 \\
\hline 6 & 13.5 & -7.5 & 56.25 & 4.19 \\
\hline 21 & 13.5 & 7.5 & 56.25 & 4.19 \\
\hline 20 & 13.5 & 6.5 & 42 & 3.12 \\
\hline 7 & 13.5 & -6.5 & 42 & 3.12 \\
\hline 21 & 13.5 & 7.5 & 56.23 & 4.19 \\
\hline 6 & 13.5 & -7.5 & 56.25 & 4.19 \\
\hline Total & & & & 31.38 \\
\hline
\end{tabular}

Source questionnaire Administered 2016

Degree of freedom $=$ d.f

D.f $=(\mathrm{r}-1)$

$=(3-1)(\mathrm{c}-1)$

$=2 \times 2$

D.f $=4$ 
Chi-square $(x 2)$ calculated $=31.38$, while critical value from chi- square table at $4 \mathrm{~d} . \mathrm{f}$ and $5 \%$ of significance is 9.488 .

\section{Decision rule:}

Since the calculated or computed value of $\times 2$ (31.38) is greater than the value of chi-square from the critical table (9.488) at 5\% level of significance, the null hypothesis that the implementation of Treasury Single Account has no influence on the liquidity and performance of the banking sector is rejected while the alternate hypothesis that the implementation of TSA has influence on the level of cash and performance of banking sector is accepted.

\section{Results AND Discussion}

From the data collected from the Management staff of the selected ten banks, the dependent variables are liquidity base and performance of the banking sector. The independent variable is the implementation of Treasury Single Account.

The relevance of the data to the variables is contained in the Table $2-4$. From the analysis and test of hypothesis, it was discovered that the implementation of Treasury Single Account influence the liquidity base and performance of the banking sector in Nigeria. It is certain that when there is liquidity problem, the performance of the banks will be affected.

\section{CONCLUSION}

The study discovered that the implementation of TSA in the public Accounting System influenced the liquidity base and performance of the banking sector. We, therefore recommend that $\mathrm{CBN}$ should come up with an arrangement to address this. Banks should source funds from other sectors of the economy; more than $50 \%$ of the population of Nigeria does not have access to financial services. Savings and investment should be encouraged instead of people keeping their money under their pillow. It entails that unwavering commitment and sincerity of purpose are needed for the system to work effectively. The choice of the TSA should be informed and guided by the availability of clear operational basis technology infrastructure that supports the implementation of the model of their choice. CBN should go beyond the guidelines and put in place measures to correct any lapses or negative impact of the policy both on the banking sector and the economy at large.

\section{THE IMPLICATION OF THE STUDY}

The implication of this study is that banks should avoid armchair activities' by meeting their customers where they are, reduce concentration given to government funds and go out to source funds from other sectors of the economy. People who were denied access to credit facilities, investments and savings opportunity should be encouraged as this will improve the economy and result from sustainable banking sector in the country. Commercial banks should adapt swiftly and look inwards to face the core functions for which they were licensed for.

\section{References}

Adeolu I. A. (2016). Understanding The Treasury Single Account (TSA) System - Things You Should Know. [(2010), Treasury]

Business \& Economy, Market Development. 265 Nairaland Forum / Nairaland / General / Politics. February 2016 
CBN (2015) "Revised Guidelines for compliance with Treasury Single Account by Banks in Nigeria,

Isaac .A. (2015), How Treasury Single Account (TSA) may affect economy. (Unpublished Paper)

Kanu \& Oyims. (2015). Financial Exclusion of Small and Medium Enterprise and Poverty Alleviation: Nigeria Experience. Archives' of'Business'Research,'3(4), pg. 63-77.

Sailendra Pattanayak and Israel Fainboim (2010), Treasury Single Account: Concept, Design and Implementation Issues. Fiscal Affairs Department (IMF Working Paper)

Taiwo . O . (2015), Does The New Treasury Single Account (TSA) Hold For Tax? PWC Nigeria.

Udoma Udo Udoma (2015), Implementation of TSA and Nigeria Economy. Chairman National Planning Commission. Nigeria. (Unpublished Paper)

\section{News Papers}

Adeboyo (2015), Implication of Treasury Single Account on Nigeria economy. News verge, Nigeria: Friday, 02 Oct 2015

Business \& Economy, Market Development. Report generated on Thu, 21 Apr 2016 22:36 Page 21 of 21

Nairaland Forum / Nairaland / General / Politics. February 2016

Premium Times Nigeria- Press Release, February, 2016

\section{Internet}

http:/ / www.vanguardngr.com/2015/08/treasurysingle- account-bank-deposits-loss-may-hit-n2trn/ http/www.nigeriannewpapers.today.

iiste.org.journals,index/php/RFJA/article/downloannairametric.com/thes-are-eight-advantages... www.info.org/external /pubs/t/wp/2010/wp. 